\title{
ON A GRAVE SYMBOL FROM NORTHWEST BELARUS
}

\author{
Andrei Prokhorov
}

\begin{abstract}
The article focuses on an interpretation of a funeral symbol found on the gravestones in Northwest Belarus - an engraved image of a pole with a semicircle at its top. The gravestones are connected to the archaeological culture of stone tombs of Yotvingian origin. Possibly, this symbol has been given a wider perspective in the world of late paganism of the Grand Duchy of Lithuania and its neighboring territories. This symbol represents an idea of 'the world axis', and its main mythological meaning has been to create a communication between the souls of the dead and the upper celestial world which has been imagined as 'the celestial mountain'.
\end{abstract}

Key words: 'celestial mountain', cosmological symbol, funerary ritual, gravestone, North Star (polestar), Slavic and Baltic mythology, 'world axis'

Among the numerous medieval gravestones in Northwest Belarus, there is a group of stones featuring an engraved image of a pole with a semicircle at its top. All these gravestones are quite simple and feature no other symbols or inscriptions. Until now, gravestones with the image of a pole with a semicircle have been found in the regions surrounding the cities of Pruzhany, Lahojsk, Orsha, Garadok, Vileyka and the village of Lukoml' (Figs. 1 \& 2). Some of these images, engraved on stones, have been published in proper scientific editions (Kviatkovskaia 1998: 32; Matulis 1990: 137-138).

\section{ON THE ORIGIN AND DATING OF GRAVESTONES}

The region where the funeral symbols in the form of a pole with a semicircle are spread offers a chance to make assumptions about the ethnicity of their founders. In Northwest Belarus the tombstones with this symbol directly continue the tradition of burials in stone tombs which were originally connected to the burials in stone barrows; also, these stones have been located near these monuments. 


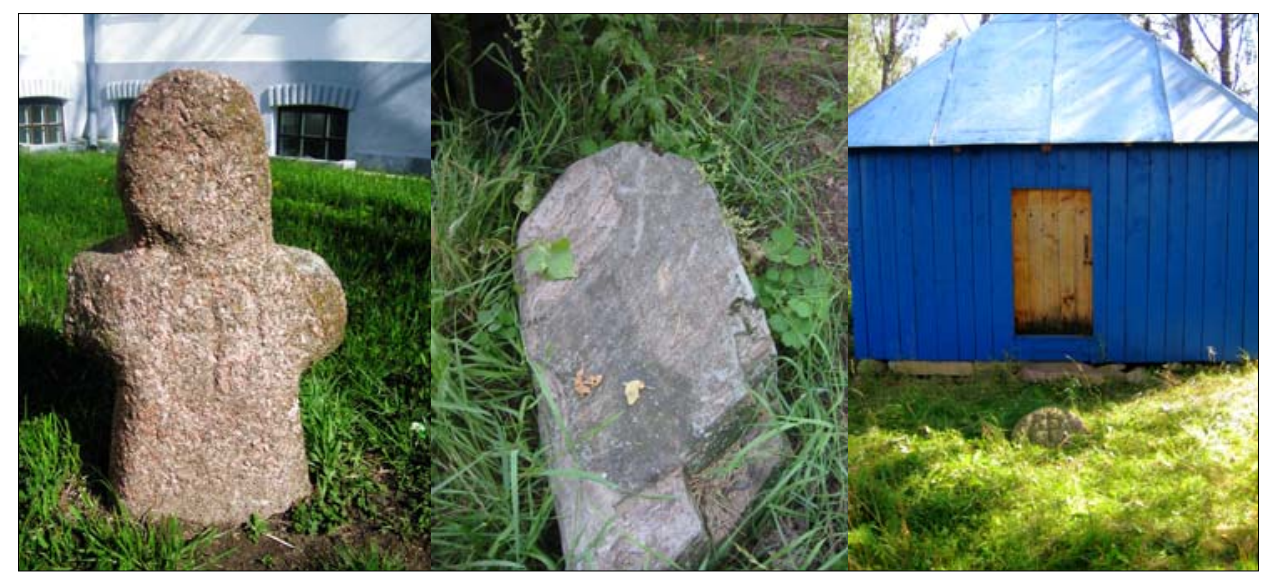

Figure 1. Examples of gravestones with the image of a pole with a semicircle.

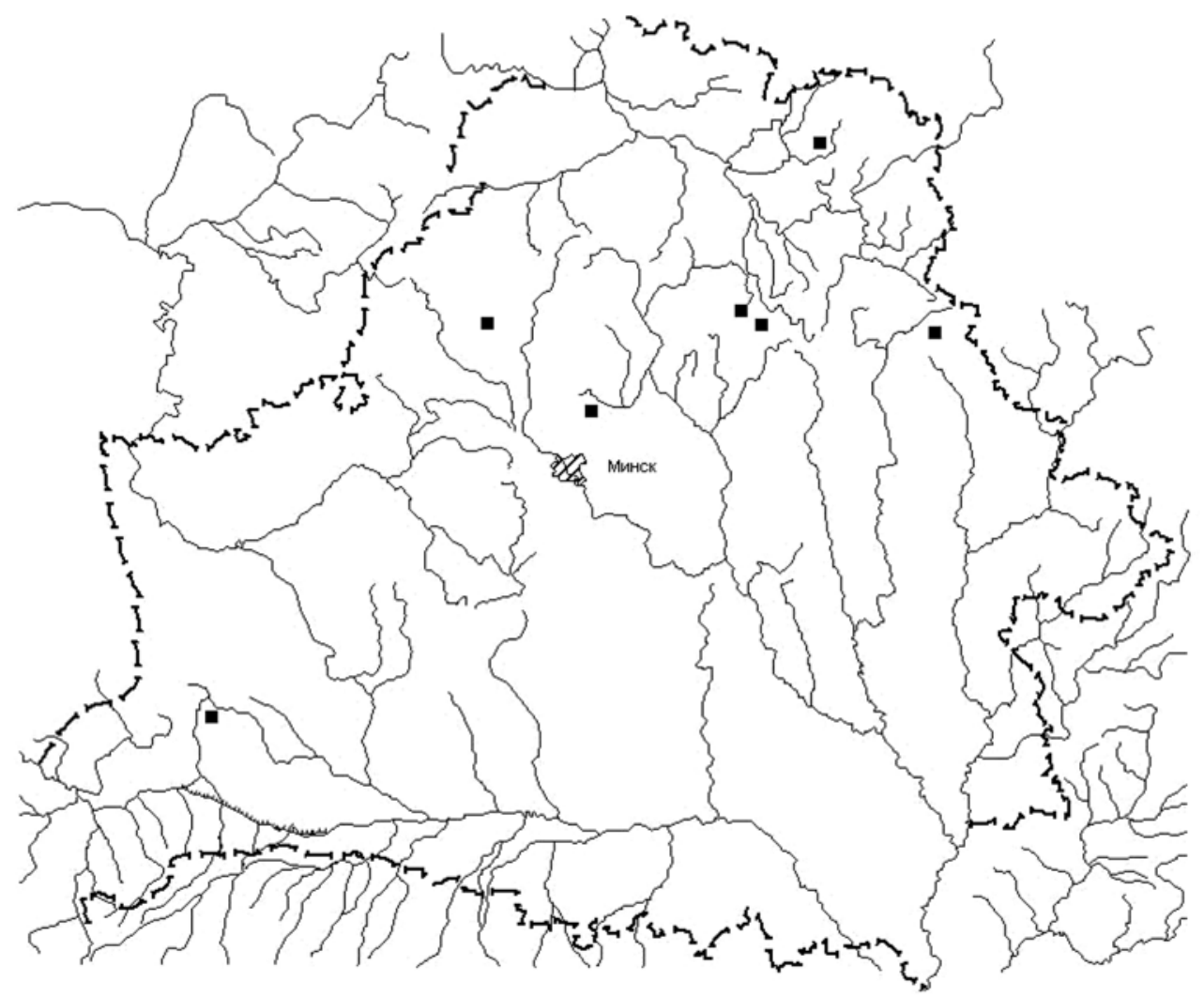

Figure 2. Distribution map of the discovered gravestones with the image of a pole with a semicircle (present situation). 


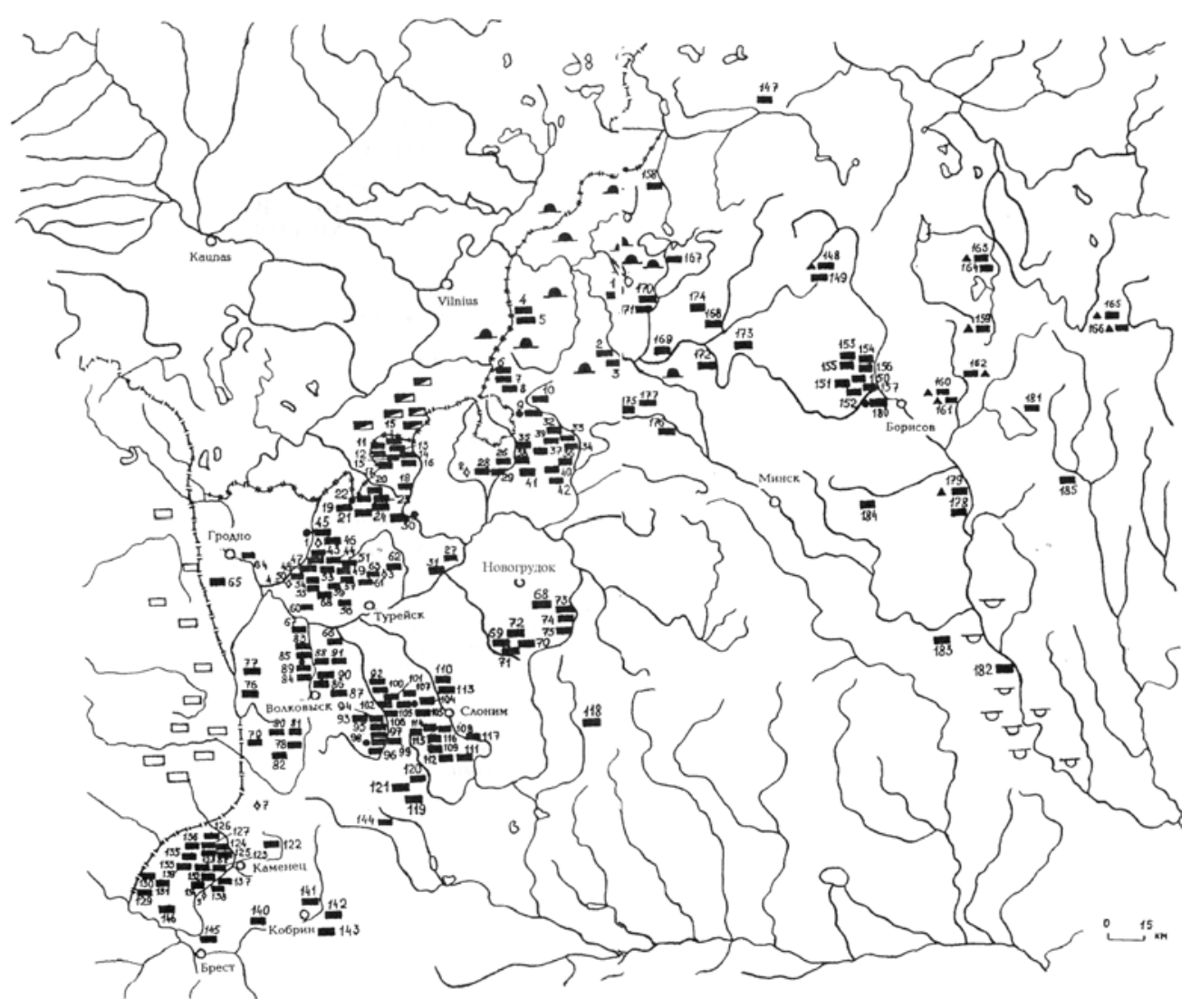

Figure 3. Map of the archaeological cultures of stone barrows and stone tombs in Northwest Belarus (Source: Kviatkovskaia 1998).

Belarusian archaeologist Alla Kviatkovskaia has drawn a distribution map of these types of burials on the territory of Belarus (Kviatkovskaia 1998: 26-27, Fig. 3). Scholars have traditionally linked the period of burial in stone barrows to the end of the 11th century, and the following period of ground burials in stone tombs in Northwest Belarus with the Baltic tribe of Yotvingians (Kviatkovskaia 1998: 176-187). ${ }^{1}$ In the funeral rituals of these cultures the pagan meaning was preserved in spite of other changes that the rituals underwent (Kviatkovskaia 1998: 173).

The gravestones with the image of a pole with a semicircle are dated either according to the late period of existence of stone tombs or of traditional burials which had replaced the stone tombs at the end of the 16th century. On the cemeteries, similar symbols appeared next to evidently Christian symbols, the crosses. 
Kviatkovskaia has distinguished certain areas inside the archaeological culture of stone tombs (Kviatkovskaia 1998: 188):

1 the right bank upstream the river of Neman;

2 the left bank upstream the Neman;

3 upstream the rivers of Bug and Jasel'da;

4 upstream the river of Vilia, midstream of the river of Biarezina, upstream the left tributes of West Dzvina, and the area of the lakes of Lepel'.

Kviatovskaia has associated the first three regions mostly with the resettling of Yotvingians, and the fourth region is included because of the close vicinity to stone tombs and barrows of the Slavic tribe of Krivichs. In addition, stone barrows of the previous period were not widespread in this region. Therefore Kviatkovskaia has associated the fourth area with the conquered Yotvingians who had been moved there by Slavic dukes after the invasion of the latter on the Yotvingian territories.

It seems that the discussion of the origin of the fourth area is not settled yet and demands more detailed archaeological research; as do the questions of when, how, and in what status did the Yotvingian population (and, possibly, other Baltic settlers) appear there.

Another important issue is whether the mentioned symbol had been assigned an unequivocal ethnic origin or had it been connected with some wider religious-mythological concepts. The region where this symbol was spread is still not finally determined. Therefore, the symbol of a pole with a semicircle on gravestones can be found further to the east - in the Orsha region. So, it is necessary carry out special research to prove the presence of the Balts on these territories. Accordingly, the region of this symbol might be expanded considerably and this problem demands even further research.

\section{SACRAL STONES}

Sometimes the image of a pole with a semicircle at the top has appeared to be a part of more complex symbolic compositions. This is an important argument in the interpretation of this image, because the connection of these composite images and burial places has not been established yet.

One good example of the complex representation is a stone found in the region of Lahojsk. It features the image of a pole with two symmetrically located semicircles and other signs. This stone is now held at the Museum of Boulders of the National Academy of Sciences of Belarus (Fig. 4). 


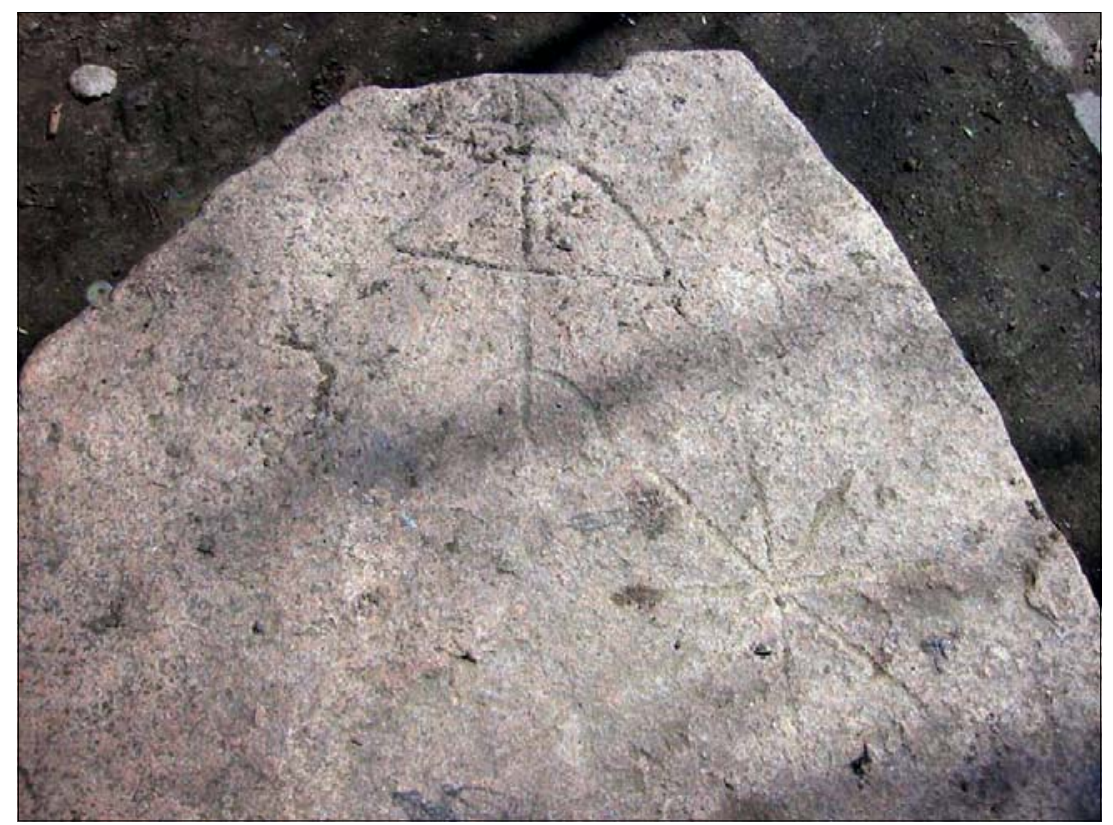

Figure 4. A stone with a pole with two semicircles and another image from Lahojsk region.

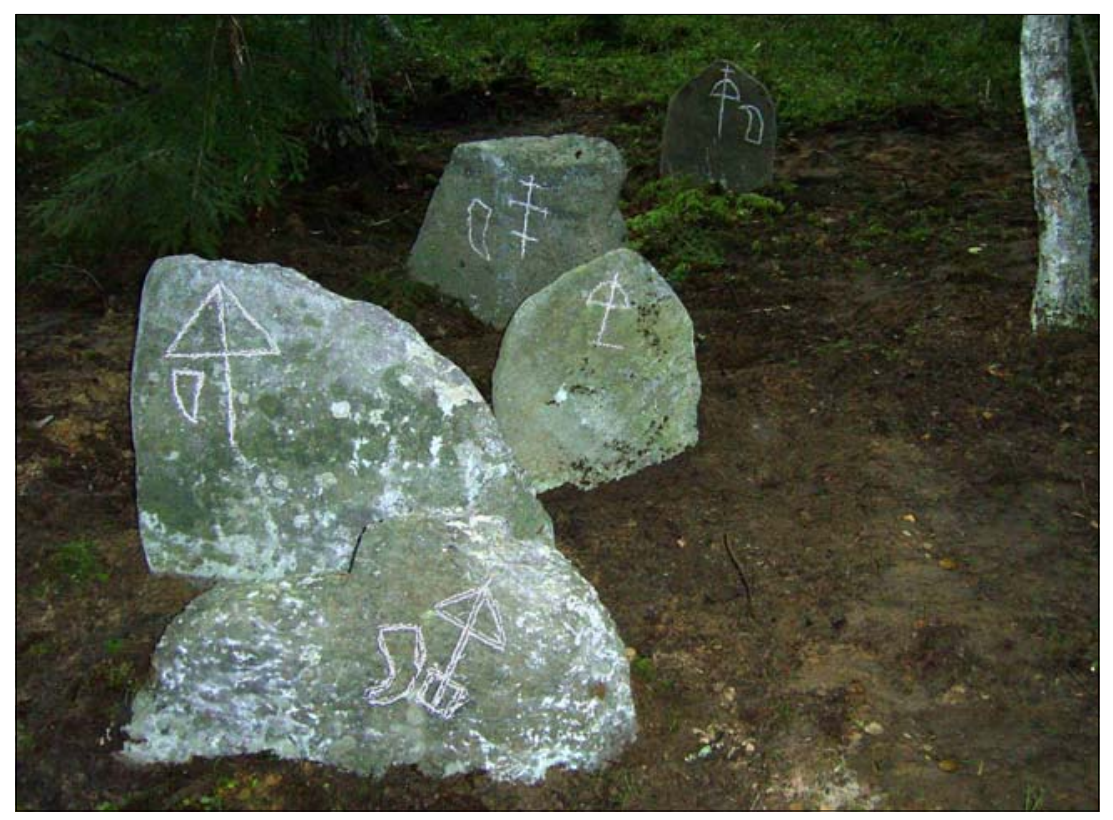

Figure 5. S'tseberaki stone complex, Vileyka district. Photo by V. Obukhovski. 
Similar engraved images of a pole and a semicircle have been found on the few stones near the village of S'tseberaki/Scebiaraky the region of Vileyka), where this image is part of a larger complex composition, which has been drawn on several stones (Fig. 5).

The stones of S'tseberaki could serve as a key to interpret the symbolical image of a pole with a semicircle. The stone complex has an astronomical orientation. The stones are orientated in the south-north direction, and to look at the images an observer faces the north. The image of a pole with a semicircle is in this projection also oriented precisely to the north and upwards.

The direct orientation to the north shows that the sign of a pole with a semicircle could be understood as a mythological axis which connects the ground surface with the North Star (polestar). The name of the North Star is often connected with the concepts of a pole, a column, and a nail in many areas of the world, including this region. The Belarusian name for the North Star is 'the Big Pole' (Karpenko 1985: 22). The name 'Pole' is widespread in some regions of Russia and among some other Slavic people, but also among Mongols and Turks (Karpenko 1985: 65). A Polish Catholic legend has stated that once there was a pole which connected the North Star with the Hell (Cetwiński \& Derwich 1987: 189). ${ }^{2}$

Thus it may be concluded that the image of a pole with a semicircle (including the ones on the gravestones) is the graphic image projection of the sphere of the sky. Such projection is the simplest representation of the sky movement during the night. Such movement creates the impression of 'the celestial dome'. The celestial sphere was fixed on and supported by 'the world pole'.

It is possible to include such stones, with their composite images with a pole and a semicircle, in the category of sacral stones. A very important argument here is the name of the village of S'tseberaki (Belarusian Сцебяракі, Сціберякі), in the vicinity of which there is the stone complex. The name can be related to the Latvian Staburags, plural Staburagi, which has a transparent etymology, deriving from Latvian stabs 'a pole' and rags 'a horn'. Here it is also important to mention the Lithuanian stabas 'a sacral stone'. This semantic layer closely corresponds to the stone complex and its images and thus leads to the conclusion that the mentioned sacral stones with the image of a world axis were the analogy of the universal world axis.

In Latvia, there used to be a boulder on the Daugava/West Dzvina called Staburags. Since the mid-1960s, the rock has been flooded by waters of an artificial water reservoir. The sacral character of this object was strongly marked. Latvian mythology includes legends about the creation of Staburags boulders by giants (Latyshskie predaniia 1962: 101-102). 
The existence of Baltic parallels is also supported by the similar carved symbols that have been discovered on some rocks within the territory of modern Latvia. The world axis forms the center of these images too. These Latvian symbols are connected with pagan cosmological representations of the space (Laime 2003: 2-20; 2004: 46-66; 2006: 53-65).

\section{SEMANTICS OF THE POLE}

The most straightforward way of decoding the symbolic meaning of a pole with a semicircle would be to compare it with the evidence of Yotvingian mythology. However, this mythology has been little discussed in written sources, and sometimes its presence may be only assumed (e.g., Toporov 1966: 143-149).

Therefore, aspiring to explain the meaning of the symbol, it is necessary to use mythological parallels from the known folk cultures such as that of the Balts (Lithuanians, Latvians, and the fragments of religious-mythological representations of other tribes), and also of the Slavs (first of all, Belarusians). Even so, it is obviously merely a regional research with regard to the background of the whole cultural zone: we are dealing with an artifact of culture which has been developed on the basis of common cultural traditions in the entire circum-Baltic region.

The symbolism of a pole and a ceremony of its installation in Slavic and Baltic cultures have their roots in old traditions of the period of paganism. Maria Gimbutas (2004: 204), the leading expert in Baltic archaeology and culture, has suggested that the symbolism of sacral poles in the Baltic culture roots in the Iron Age.

It is possible to distinguish at least three major semantic forms of the ceremony of setting up the pole or its analogies as a ceremonial or ritual 'pillar of the world':

- erecting the pole for performing calendar rites;

- the sacrality of a central pillar in a residential house;

- setting up a pole or using the pillar of the house during special rituals, for example, at weddings, and particularly at funerary rituals, which will be discussed at greater length below.

Setting up a pole was an integral part of some calendar rites among the Slavs and the Balts. Erecting the pole during feasts on Pancake Week and on Kupal'e is the most popular ceremonial action of the Eastern Slavs. The top of the pole had been often crowned with a solar sign, and the poles were at the heart of all ritual actions. For example, the ancient origin of the Kupal'e ceremony on the 
territory of Belarus is evident from the ancient ritual of lighting the Kupal'e bonfire, which was lit by friction (Bessonov 1871: 62).

The installation of a pole on the day of summer solstice - on Kupole or Rasa - is also typical of Lithuanians. In East Lithuania, three branches were placed at the top of a pole with explanation that they were the Sun, the Moon and the Star. It is natural to merge the meanings of a pole and the tree of the Sun Saules Medis - of Kupole and Rasa. The cosmological semantics of the installed pole is clearly evident in calendar rites.

The central (main) column of a residential house of the Slavs and the Balts, which supported the roof, was particularly venerated. The central pillar was the most significant aspect in the ritual life of every Eastern Slavic family (Baiburin 2005: 174). Remnants of the sacral nature of these pillars have been better preserved by Belarusians: for example, very ancient names are used for the central pillar in Belarusian language, such аs дзед 'grandfather', каневы слуп "horse's column" or simply конь 'horse'. For a long time the latter have been compared with the Sanskrit aśva-yupa 'horse pole' which was represented as 'a world pole'. This name can be of very ancient Indo-European heritage (Baiburin 2005: 174; Ivanov 1974: 75-138). Also, the column that supports the roof of the house in Lithuania can be compared to 'the world pole'. The cosmological semantics has been emphasized by the engraved symbols of the Sun, the Moon, and the stars on the upper part of the column and with the images of horses or grass-snakes on its lower part (Gimbutas 2004: 203-204).

The most significant manifestation of the ritual role of the central column in Belarusian houses is the wedding ceremony which has been named столбовой обряд 'the column rite', because the basic actions took place around the column. Gods were believed to be present at the central column, the ritual appeal to gods with its request to "forge" the wedding was announced, and also the main ceremony to unite the newly-weds was carried out there. Belarusian scholar Nikolai Nikolskii has compared this column of houses with family altars of the Ancient Near East (Nikolskii 1956: 144-176).

Sometimes special rituals of setting up a pole were carried out in the Baltic region. Lithuanians had a tradition of putting up special poles in case of important events, such as marriage, illness, epidemics, and good harvest (Gimbutas 2004: 204). Maria Gimbutas has proposed a cosmological meaning for such poles with symbols of the Sun, the Moon, and the stars on their top.

Thus, the mythological semantics of the pole represents, first of all, certain cosmological ideas which could be applied in various situations of different religious significance. Its aim was to create sacral communication with the universe at a specific ritual moment, such as calendar and family feasts, construction of dwelling, epidemics, etc. ${ }^{3}$ 


\section{FUNERAL CEREMONY}

Why does the cosmological sign appear on gravestones? The symbolism of a pole on a tomb is well known in the ancient funerary rituals of many archaeological cultures of the region under discussion. The tradition to set up a pole is also very closely connected with some funerary rituals of the Slavs and the Balts.

However, it is not always possible to trace the evolution of a funerary ceremony, especially the changes in its religious and mythological concepts in detail on the basis of existing written sources; particularly when the subject deals with particular ethnic or social groups.

Many ancient East-Slavic tribes erected poles on tombs. The Primary Chronicle, which describes the customs of the tribes of Radimichs, Vyatichi and Severians in the 9th-10th century, mentioned that

если кто умирал, то устраивали по нем тризну, а затем делали большую колоду, и возлагали на эту колоду мертвеца, и сжигали, а после, собрав кости, вкладывали их в небольшой сосуд и ставили на столбах по дорогам, как делают и теперь еще вятичи. Этого же обычая держались и кривичи, и прочие язычники, не знающие закона Божьего, но сами себе устанавливающие закон. (Povest' 1999: 11, 147)

[when somebody died, they arranged a funeral feast - tryzna, and then made a big block of timber, and placed the dead man on this block, and burned it, and after collecting the bones put them into a small vessel and put the latter on poles on roads as Vyatichi are still doing now. The same custom is followed by the Krivichs and other pagans, ignorant of the law of God, but establishing their law by themselves. (Author's translation.)]

The krikštai, wooden poles which symbolized a sacred 'world tree' - are considered to be the oldest gravestone monuments in the Lithuanian tradition. These poles assisted the spirits of the dead on their ascent to the upper world (Straižys \& Klimka: n.d.). Subsequently, the sacred grove had grown around these funeral poles.

The funeral ceremonies of the Dukes of the Grand Duchy of Lithuania offer the most detailed description, and even allow us more or less precisely trace the evolution of the ceremony. Essentially, the annals describe burial places at specially chosen natural sites. The chronicler described the funeral of the legendary Duke Kukovoit/Kukovaitis (mentioned in the Chronicles of the mid13 th century) though obviously did not mention whether his corpse had been cremated. The son of Kukovoit having buried the Duke, 
учинил болвана на память отца своего и поставил его на горе однои над рекою Светою [...], которого ж фалили и за бога его мели. И потом того болвана згинул, гаи вырос и люди тым фалили и прозвали его именем пана своего Куковойтя. (Letopis' 1980: 92)

[made an idol in memory of his father and placed it on a mountain above the river Sveta [...] and it was worshipped and considered as the god. And then, when the idol disappeared, the grove had grown and the people had worshiped it and had called it in the name of their lord Kukovoit. (Author's translation.)]

The chronicler made an important addition to his description of the funeral of Princess Pojata (mentioned in the Chronicles of the mid-13th century) when her son учинил болвана образом ее 'made an idol that looked like herself', which means that he had given the idol (pole) an anthropomorphous figure (Letopis'1980: 91-92).

Subsequently, the funeral ceremony changed and the cremation ritual was described differently. The corpses of the dukes were burnt and ashes buried in various places: жыгали тела мертвых на том месцы, хто где умрет, 'burnt the corpses of the dead in the place where the man had had died' (Letopis' 1980: 92). After the testament of the legendary Duke Shvintorog/Šventaragis (the Chronicles mention his death at the end of the 13th century) the ceremony became to be held traditionally in a sanctuary in Vilnia/Vilnius. The chroniclers described this new ceremony in great detail. After a corpse had been burned together with many personal items and symbols of authority,

теды зобравши порох его, напотым ховали в землю, кладучи при них рысии и медвежии ногти для того, ижъ мает быти судный день, и так мовили, же приидет бог судити людей и сядет на горе высокой, судячи справедливых и грешных, на котрую гору трудно будет влезсти без ногтей рысих або медвежиих на той суд до бога (Khroniki 1975: 31).

[they collected the ashes, then buried these in the soil, having covered it with lynx and bear claws, for it would be a Doomsday, and they spoke that the god would come to judge people and would sit down on a high mountain, judging fair and sinful men, it would be difficult to get on that mountain for that judgment of the god without lynx or bear claws. (Author's translation.)]

The Chronicle of the Grand Duchy of Lithuania and Samogitia describes the funerals of several dukes -the legendary Shvintorog/Šventaragis, Gedemin/ Gediminas in the year 1341 and, finally, Kejstut/Kęstutis in 1382 - which fol- 
lowed the same ceremony (Khroniki 1975: 41-42). Subsequently, Maciej Stryjkovsky repeated the descriptions of the funeral ceremony of the Lithuanian Dukes (Kronika 1985: Vol. 1: 308-309, 385-386; Vol. 2: 65).

The most recent folklore sources also explain the meaning of the ceremony - the dead are believed to "clamber" over a 'glass' or 'abrupt stone' rock where the supreme deity will be waiting for them. In Lithuanian folk songs, the Sun dances "on a silver mountain in silver boots" on a day of summer solstice on June 24th (Gimbutas 2004: 210). The image of a mythological mountain has been connected with a celestial dome (Gimbutas 2004: 198).

Though the souls of the dead "clambered" over the sky mountain, the true target destination of their travel was the space behind the mountain (Gimbutas 2004: 198). The manor of god Dievas was located "in the sky behind the stony, silver, golden or amber mountain. Dievas descended from that mountain on a horse either in a chariot or in a sledge of gold and copper" (Gimbutas 2004: 209).

For the sake of the research it is important to point out the following motifs in Lithuanian folklore regarding the far country in the West: the land from where the sun comes and where there are "a grey stone and a solar tree or an iron pole, and two horses adjacent to that pole" (Gimbutas 2004: 198). Thus, the other world is also structured around a pole or a tree which supports the celestial dome.

As a result, in the light of the funeral ceremonies of the Slavs or the Balts, it is clear that the main purpose of all the listed rituals was to assist the souls of the dead on their journey to the other world. The road towards the world leads upward, to the sky.

Archaeological investigations offer us a good opportunity to observe how various ideas about the pathway to the other world were reflected in specific funeral rituals. Moreover, according to a well-known Lithuanian pagan custom to bury the dead with his horse, the aspiration or belief that it should be the horse which carries the dead to the upper world, is clearly visible. The Treaty of Christburg in 1249, imposed by the Teutonic Order to Prussians, prohibited the latter from obeying the pagan priests, who

ac erectis in celum luminibus exclamantes, mendaciter asserunts se videre presentem defunctum per medium celi volantem in equo, armis fulgentibus decoratum, nisum in manu ferentem et cum comitatu magno in aliud seculum procedentem (Treaty 1959: 500-501).

[having their eye lifted to the heavens, delusively exclaim that they see the dead man who had been laid down, flying above in the sky on a horse; that man is decorated with a brilliant weapon, bearing a falcon on 
his hand, and is travelling to the other world with his big retinue. (Author's translation.)]

These ideas indicate that the funeral custom of the archaeological culture of stone tombs where the image of a pole with a semicircle was depicted on gravestones served the same purpose. This cosmological symbol served to present a mythological basis for communicating with the upper world, and thus created a proper cosmological projection. Putting up a stone with an image of a pole with a semicircle could have been simply an alternative to erecting a pole. This may have occurred under the influence of other traditions; for example, the Christian burial stones. Also, a gravestone with this image was the representation of the world axis.

\section{THE DWELLING PLACE OF SOULS}

Nevertheless, despite the main purpose of a funeral ceremony to escort the soul of the dead to the other, upper world, more recent Lithuanian folklore and legends describe some other places of posthumous soul residence or of the soul's short visit to the world of the living. The presence of the souls of the dead in the neighborhood was expressed in the world of the living in funeral objects such as barrows, poles, and stones.

There is a concept in Lithuanian folklore that vele, the spirits of the dead, live in 'a sandy mountain', 'the mountain of the dead', that is, a funeral barrow (Gimbutas 2004: 197). The custom of putting up gravestones has probably led to the belief that vele are staying on, under, or around these stones.

Vele are also believed to sit on a pole. In some regions of Lithuania, where this tradition survived until the 20th century, funeral poles have been often carved with images of horses, birds, snakes, flowers, sometimes with symbols of stars (Čepienè 2000: 45).

During the Christian era, a transition from a pole to a cross occurred. Thus the local population associated even the cross with the pagan context. It is obvious that the Roman Catholic clergy understood the context and aspired to fight against it. In the year of 1426, the Bishop of Sambia imposed his prominent ban on putting crosses on the cemetery; so it evidently shows the pagan basis of the local Baltic tradition (Čepienè 2000: 45). ${ }^{4}$

It is interesting that in some regions, the Christian cross assumed a special form with a roofed top. In the Lithuanian tradition this represented the house of the soul of the dead, and then, to disguise that idea, people started to place figures of the Christian saints there (Čepiene 2000: 47). This leads, again, to the semantics of the most ancient funeral columns. 


\section{FUNERAL BARROW}

Among the composite images with the symbol of a pole with a semicircle from Northwest Belarus, there is a unique variant with some hemispheres consistently located one above the other (Fig. 4 see p. 43). In this case, the symbolism of a pole with several semicircles helps us to explain the mythological idea on how the souls of the dead were believed to be simultaneously in the sky and "the next door" to the world of the living.

The pole with a semicircle could be viewed not only as an ideal symbol of the celestial sphere but allows another speculation. A pole with a semicircle can be connected simultaneously with the structure of a funeral barrow of the Balts and the Slavs, and also seen as a structural model of the universe. Such is the case with the images of several hemispheres on one pole. The barrow could be interpreted as another sphere, another world alongside the upper celestial world.

Here, attention should be drawn to an important feature of the barrows of Yotvingians. These barrows were surrounded and covered by a bank of stones or, more likely, initially consisted of piled stones. Such burials in the barrows surrounded by stones represent a very old tradition and date back to the first half of the second millennium BC in the Baltic area.

This type of funeral barrow was added to cosmological symbolism alongside the celestial sphere. It corresponds to a mythological idea about the stone sky, which was widespread among Indo-Europeans (Maher 1973), and among the Balts in particular. For example, one can mention the legends in which thunder is the noise of Perkūnas' chariot riding over the stone road.

This provides the key to understand the mythological idea of the Baltic folklore that the souls of the dead ancestors exist simultaneously in the upper celestial world and near the world of the living in various funeral objects. These worlds were connected by the funeral 'world axis', which, in the form of a pole or symbolical images, enabled a migration between the worlds.

During the feast, which was devoted to the veneration of the ancestors, the living met the souls of these ancestors in burial places. In this case, the pole or the symbol of a pole with a semicircle embodied not only an opportunity of traveling upward, but also the idea of a possible brief return to this world.

The results of regional research in Northwest Belarus can be confirmed with typological similarity of images on some stones in Scandinavia and their mythological semantics. Russian historian Vladimir Petrukhin has proposed a very precise definition of mythological semantics of composite images of the rune stones in Sweden. 
Thus, memorable stones were an analogue of the world tree, connecting all the worlds, guided the dead on the way to the kingdom of the dead. The majority of monuments reveal that various pictures, which depict traveling into the other world, are united by the general 'model' of the world. Their cult role was to guarantee the "persistence" of cosmic space and social order, a "normal distribution" between the living and the dead in this world and the other, and also the contact between these worlds, which had been established within the cult of ancestors (Petrukhin 1978: 160).

\section{CONCLUSION}

The interpretation of the funeral ceremony, proposed here, which has been revealed by the universal cosmological models used by representatives of the archaeological culture of stone tombs, offers a chance to explain why the schematic cosmological image - a pole with a semicircle - has been once accepted as a symbol of establishing communication between the different worlds on gravestones. Could this symbol have replaced the setting up a ritual pole? There is no doubt that the symbol was, at least originally, assigned a pagan origin and had been used by pagans themselves. On the other hand, this symbol could correspond to the image of the True Cross on Calvary, a very popular Christian funeral symbol.

It was really a symbol of many meanings which incorporated the concept of the traveling of the souls of the dead to the upper celestial world. Similar sacred stones or gravestones which have the image of a celestial sphere and are situated deeper in the ground became the link between the different worlds, strengthening and simultaneously testifying the integrity of space.

As a result, it is possible to conclude that the gravestone image of a pole with a semicircle symbolized the world pole which was oriented to the North Star, connected the ground with it, and thus supported the celestial sphere, or 'the celestial mountain' in the Baltic mythology.

\section{NOTES}

${ }^{1}$ Some scholars have suggested the Slavic origin of stone barrows, at least, in some regions (e.g., Korobushkina 1993).

2 The tradition of setting up ceremonial columns which were oriented to the North Star was known in other regions. For example, the North-American tribe of Omaha also conducted a very special calendar ritual with this procedure (Krapp 2000: 531-543). 
${ }^{3}$ An important mythological category of 'setting up the pole' during the cosmological creation within German pagan tradition has been substantially researched by the Russian linguist Tatiana Toporova (1994: 21, 36-37, 84-85, 94-95, 137).

${ }^{4}$ Similar transition from the worship of a pagan 'world pillar' Irminsul to the Christian cross is known in the Germanic tradition (Krapp 2000: 543).

\section{REFERENCES}

Baiburin, Albert K. 2005. Zhilishche v obriadakh i predstavleniiakh vostochnykh slavian. [Dwelling in the Rituals and Representations of the Eastern Slavs.] Moskva: Izdatel'stvo iazyki slavianskoi kul'tury.

Bessonov, Petr A. 1871. Belorusskie pesni. [Belarusian Songs.] Moskva: Tipografia Bakhmeteva.

Čepienè, Irena 2000. Historia litewskiej kultury etnicznej. [History of Ethnic Culture in Lithuania.] Kaunas: Šviesa.

Cetwiński, Marek \& Derwich, Marek 1987. Herby, legendy i dawne mity. [Coats of Arms, Legends, Ancient Myths.] Wroclaw: Państwowe Wydawnictwo Naukowe.

Gimbutas, Maria 2004. Balty: Liudi iantarnogo moria. [The Balts: People of the Amber Sea.] Moskva: Tsentrpoligraf.

Ivanov, Viacheslav V. 1974. Opyt istolkovaniia drevneindiiskikh ritual'nykh i mifologicheskikh terminov obrazovannykh ot aśva - kon' (zhertvoprinoshenie konia i derevo aśvattha $\mathrm{v}$ drevnei Indii). [An Essay on the Interpretation of Ritual and Mythological Terms Derived from Aśva-'horse' (The Offering of a Horse and the Aśvattha Tree in Ancient India).] In: G.A. Zograf \& V.N. Toporov (eds.) Problemy istorii iazykov i kul'tury narodov Indii. Moskva: Nauka.

Karpenko, Yuri A. 1985. Nazvaniia zvezdnogo neba. [Names of the Stellar Sky.] Moskva: Nauka.

Khroniki 1975 = Khroniki: Litovskaia i Zhmoitskaia, i Bykhovtsa. In: Polnoe sobranie russkikh letopisei. [The Full Collection of Russian Chronicles.] Vol. 32. Moskva: Nauka.

Korobushkina, Tatiana N. 1993. Kurgany Belorusskogo Pobuzh'ia.X-XIII vv. [Barrows in the Region of the Bug River in Belarus in the 10th-13th Century.] Minsk: Navuka i tekhnika.

Krapp, Edvin 2000. Legendy i predaniia o Solnce, Lune, zvezdakh i planetakh. [Tales and Legends about the Sun, the Moon, the Stars and Planets.] Moskva: Izdatel'sko-torgovyi dom "Grand".

Kronika 1985 = Kronika Polska, Litewska, Żmódzka i wszystkiej Rusi Macieja Stryjkowskiego. 1952. [Chronicle of Poland, Lithuania, Samogitia, and all of Ruthenia of Kiev, Moscow, Novgorod...] Warszawa: Wydawnictwa Artystyczne i Filmowe, Poznańskie Zaklady Graficzne. Vols. 1-2.

Kviatkovskaia, Alla V. 1998. Iatviazhskie mogil'niki Belarusi (konec XI-XVII vv.) [Yotvingian Cemeteries in Belarus (From the Late 11th to the 17th Century).] Vilnius: Diemedzio. 
Laime, Sandis 2003. Cosmological Ideas in Latvian Rock Carvings and Distaff Designs. Cosmos. The Journal of the Traditional Cosmology Society. Vol. 19, pp. $2-$ 20.

Laime, Sandis 2004. Traces of Rituals in Latvian Rock Carvings. Aurinkopeura. Tartu: Eesti Muinastaideselts \& Suomen Muinaistaideseura, Vol. 2, pp. 46-66.

Laime, Sandis 2006. Kosmologiskie priekšstati latvijas klinšu rakstos un sprēslīcu ornamentos. [Cosmological Representations in Latvian Rock Inscriptions and Ornaments on Distaffs.] In: Kultūras krustpunkti. 3. Laidiens. Latvijas Kultūras akadēmijas zinātnisko rakstu krājums. Riga: Latvijas Kultūras akadēmija, pp. $53-65$.

Latyshskie predaniia 1962 = Latyshskie narodnye predaniia. Izbrannoe. [Latvian Legends.] Riga: Izdatel'stvo Akademii Nauk Latviiskoi SSR.

Letopis' 1980 = Letopis' Arkeologicheskogo obshchestva. [Chronicles of the Archaeological Society.] In: Polnoe sobranie russkikh letopisei. [The Full Collection of Russian Chronicles.] Vol. 35. Letopisi belorussko-litovskie. Moskva: Nauka.

Maher J. Peter 1973. *Ha $\mathrm{H}_{\mathrm{a}}$ ekmon: '(Stone) Axe' and 'Sky' in IE/Battle-Axe Culture. Journal of Indo-European Studies. Vol. 1, No. 4, pp. 44-462.

Matulis, Rimantas 1990. Istoriniai akmenys. [Historical Stones.] Vilnius: Eksperim. Technikos Paminklu.

Nikolskii, Nikolai M. 1956. Proiskhozhdenie i istoriia belorusskoi svadebnoi obriadnosti. [The Origin and History of Belarusian Wedding Rites.] Minsk: Izdatel'stvo Akademii Nauk Belorusskoi SSR.

Petrukhin, Vladimir Y. 1978. O kartine mira u skandinavov-iazychnikov (po "pamiatnym kamniam" V-XI vv.) [The Worldview of Scandinavian Pagans (On "Memorial Stones" in the 5th-11th Century).] In: Skandinavskii sbornik. Skrifter om Skandinavien. Vol. 23. Tallinn: Olion.

Povest' 1999 = Povest' vremennykh let. [The Primary Chronicle.] Sankt-Peterburg: Nauka. Straižys, Vytautas \& Klimka, Libertas [n.d.] Cosmology of the Ancient Balts. Available at http://www.lithuanian.net/mitai/cosmos/baltai2.htm, last accessed in July 2009 .

Toporov, Vladimir N. 1966. Ob odnoi "iatviazhskoi" mifologeme v sviazi so slavianskoi parallel'iu. [On a "Yotvingian" Mythologeme with Related Slavic Parallels.] Acta Baltico-Slavica. Vol. 3. Bialystok.

Toporova, Tatiana V. 1994. Semanticheskaia struktura drevnegermanskoi modeli mira. [Semantic Structure of an Old Germanic World Model.] Moskva: Radiks.

Treaty 1959 = Khristburgskii (Kishporkskii) dogovor 1249 g. [Treaty of Christburg 1249.] In: V. T. Pashuto (ed.) Obrazovanie Litovskogo gosudarstva. [Origin of the Lithuanian State.] Moskva: Izdatel'stvo Akademii Nauk USSR. 